\title{
Up-Regulation of Excitatory Amino Acid Transporters EAAT1 and EAAT2 by B-Klotho
}

\author{
Jamshed Warsia,b Abeer Abousaaba Florian Lang ${ }^{\mathrm{a}}$
}

aDepartment of Physiology I, University of Tübingen, Tübingen, Germany; 'bepartment of Physiology, Univesity of Sindh, Jamshoro, Pakistan

\section{Key Words}

$\mathrm{SLC} 1 \mathrm{~A} 3 \cdot \mathrm{SLC} 1 \mathrm{~A} 2 \cdot$ Neuronal excitation $\cdot$ Glutamate $\cdot$ Klotho $\cdot \beta$-glucuronidase

\begin{abstract}
Background/Aims: Klotho, a transmembrane protein expressed in chorioid plexus of the brain, kidney, and several other tissues, is required for inhibition of $1,25(\mathrm{OH})_{2} \mathrm{D}_{3}$ formation by FGF23. The extracellular domain of Klotho protein could be cleaved off, thus being released into blood or cerebrospinal fluid. At least in part by exerting $\beta$-glucuronidase activity, soluble klotho regulates several ion channels and carriers. Klotho protein deficiency accelerates the appearance of age related disorders including neurodegeneration and muscle wasting and eventually leads to premature death. The present study explored the effect of Klotho protein on the excitatory glutamate transporters EAAT1 (SLC1A3) and EAAT2 (SLC1A2), $\mathrm{Na}^{+}$coupled carriers clearing excitatory amino acids from the synaptic cleft and thus participating in the regulation of neuronal excitability. Methods: cRNA encoding EAAT1 or EAAT2 was injected into Xenopus laevis oocytes and glutamate $(2 \mathrm{mM})$-induced inward current $\left(\mathrm{I}_{\mathrm{Glu}}\right)$ taken as measure of glutamate transport. Measurements were made without or with prior $24 \mathrm{~h}$ treatment with soluble B-Klotho protein $(30 \mathrm{ng} / \mathrm{ml})$ in the absence and presence of $\beta$-glucuronidase inhibitor D-saccharic acid 1,4-lactone monohydrate (DSAL,10 $\mu \mathrm{M})$. Results: $\mathrm{I}_{\text {Glu }}$ was observed in EAAT1 and in EAAT2 expressing oocytes but not in water injected oocytes. In both, EAAT1 and EAAT2 expressing oocytes $\mathrm{I}_{\mathrm{Glu}}$ was significantly increased by treatment with soluble B-Klotho protein, an effect reversed by DSAL. Treatment with B-klotho protein increased significantly the maximal transport rate without significantly modifying the affinity of the carriers. Conclusion: B-Klotho up-regulates the excitatory glutamate transporters EAAT1 and EAAT2 and thus participates in the regulation of neuronal excitation.

J. Warsi and A. Abousaab contributed equally thus shared the first authorship




\section{Introduction}

Klotho is expressed mainly in kidney and choroid plexus [1, 2]. The extracellular domain of the Klotho protein may be cleaved off and function as enzyme with $\beta$-glucuronidase activity [3-7]. Klotho has a powerful impact on aging and life span [8,9]. As shown in mice, klotho deficiency leads to severe growth retardation, accelerated appearance of several age related disorders, as well as dramatic shortening of the life span [9], whereas over-expression of klotho extends the life span $[9,10]$.

Klotho is effective in part by mediating the inhibitory effect of FGF23 on $1 \alpha$-hydroxylase and thus $1,25(\mathrm{OH})_{2} \mathrm{D}_{3}$ (calcitriol) formation [2, 8, 11-14]. Calcitriol in turn stimulates Klotho expression [15] as well as intestinal and renal $\mathrm{Ca}^{2+}$ and phosphate transport $[16,17]$. The excessive $1,25(\mathrm{OH})_{2} \mathrm{D}_{3}$ formation in klotho deficient mice $[2,13,14]$ is followed by increase of plasma $\mathrm{Ca}^{2+}[18]$ and phosphate [17] concentrations as well as vascular calcification [19]. Klotho further more directly influences several transport proteins including $\mathrm{Ca}^{2+}$ channels [20], $\mathrm{Na}^{+}$,phosphate cotransport $[4,21], \mathrm{Na}^{+} / \mathrm{K}^{+}$ATPase [22], renal outer medullary $\mathrm{K}^{+}$ channels [23], KCNQ1/KCNE1 [24] and the excitatory amino acid transporters EAAT3 and EAAT4 [25].

Excitatory amino acid transporters (EAATs) influence neuroexcitation by clearance of the excitatory neurotransmitters glutamate and aspartate from synaptic clefts [26-30]. EAAT isoforms particularly important for the regulation of neuroexcitation are the excitatory amino acid transporter isoforms EAAT1 (SLC1A3) and EAAT2 (SLC1A2) [26, 31, 32]. EAAT1 [33-41] and EAAT2 [42] are both expressed in astrocytes. Moreover, EAAT1 is expressed in oligodendrocytes [43, 44], neurons [45-47], retina [48, 49], taste buds [50], cochlea [51, 52], vestibular organ [53], circumventricular organ [33], adrenal and pineal glands [54, 55] as well as bone cells [56-59]. EAAT2 may confer neuroprotection [60] and impaired expression or activity of EAAT2 is followed by neuroexcitotoxicity [61-64].

The present study explored, whether the function of EAAT1 and/or EAAT2 is sensitive to $ß$-Klotho protein. To this end, EAAT1 or EAAT2 expressing Xenopus laevis oocytes were treated with $\beta$-Klotho protein and glutamate induced current determined by dual electrode voltage clamp.

\section{Materials and Methods}

\section{Ethical Statement}

All experiments conform with the 'European Convention for the Protection of Vertebrate Animals used for Experimental and other Scientific Purposes' (Council of Europe No 123, Strasbourg 1985) and were conducted according to the German law for the welfare of animals and the surgical procedures on the adult Xenopus laevis frogs were reviewed and approved by the respective government authority of the state Baden-Württemberg (Regierungspräsidium) prior to the start of the study (Anzeige für Organentnahme nach §36).

\section{Constructs}

Constructs encoding human wild-type EAAT1 [65] and human wild-type EAAT2 [66-68], were used for generation of cRNA as described previously $[69,70]$.

Voltage clamp in Xenopus oocytes

Xenopus oocytes were prepared as previously described [71, 72]. $10 \mathrm{ng}$ cRNA encoding EAAT1 or EAAT2 were injected on the same day after preparation of the oocytes. The oocytes were maintained at $17^{\circ} \mathrm{C}$ in ND96-A, a solution containing (in mM): $88.5 \mathrm{NaCl}, 2 \mathrm{KCl}, 1 \mathrm{MgC1}_{2}, 1.8 \mathrm{CaC1}_{2}, 2.5 \mathrm{NaOH}, 5 \mathrm{HEPES}$ ( $\mathrm{pH} 7.4$ ), 5 sodium pyruvate $\left(\mathrm{C}_{3} \mathrm{H}_{3} \mathrm{NaO}_{3}\right)$, Gentamycin $(100 \mathrm{mg} / \mathrm{l})$, Tetracycline $(50 \mathrm{mg} / \mathrm{l})$, Ciprofloxacin $(1.6 \mathrm{mg} / \mathrm{l})$, and Theophiline (90 mg/l) [73, 74]. Where indicated, $30 \mathrm{ng} / \mathrm{ml} ß$-Klotho protein and/or $10 \mu \mathrm{M} \beta$-glucuronidase inhibitor DSAL were added to the respective solutions. The voltage clamp experiments were performed 
at room temperature 3 days after the first injection [70,75]. Glutamate induced currents were taken as a measure of glutamate transport [76, 77]. The holding potential was $-70 \mathrm{mV}$.The data were filtered at $10 \mathrm{~Hz}$ and recorded with a Digidata A/D-D/A converter (1322A Axon Instruments) and Clampex 9.2 software for data acquisition and analysis (Axon Instruments) [78-80]. The control superfusate (ND96-B) contained (in $\mathrm{mM}$ ): $93.5 \mathrm{NaCl}, 2 \mathrm{KCl}, 1.8 \mathrm{CaCl}_{2}, 1 \mathrm{MgCl}_{2}, 2.5 \mathrm{NaOH}$ and 5 HEPES (pH 7.4). The flow rate of the superfusion was approx. $20 \mathrm{ml} / \mathrm{min}$, and a complete exchange of the bath solution was reached within about $10 \mathrm{~s}$ [8183]. For kinetic analysis the glutamate induced-current $\left(\mathrm{I}_{\mathrm{Glu}}\right)$ was plotted against the respective glutamate concentration $(s)$ and maximal current $\left(\mathrm{I}_{\max }\right)$ as well as concentration required for halfmaximal current $\left(k_{m}\right)$ calculated using the equation $\mathrm{I}_{\mathrm{Glu}}=\mathrm{I}_{\max } \cdot \mathrm{s} /\left(\mathrm{k}_{\mathrm{m}}+\mathrm{s}\right)$.

\section{Statistical analysis}

Data are provided as means $\pm S E M, n$ represents the number of oocytes investigated. As different batches of oocytes may yield different results, comparisons were always made within a given oocyte batch. All voltage clamp experiments were repeated with at least 3 batches of oocytes; in all repetitions qualitatively similar data were obtained. Data were tested for significance using ANOVA or t-test, as appropriate. Results with $p<0.05$ were considered statistically significant.

\section{Results}

The present study explored the effect of the ß-Klotho protein on electrogenic glutamate transport by the excitatory amino acid transporters EAAT1 and EAAT2. To this end, EAAT1 or EAAT2 expressing Xenopus laevis oocytes were left untreated or were treated with ß-klotho protein $(30 \mathrm{ng} / \mathrm{ml})$ and glutamate-induced inward current $\left(\mathrm{I}_{\mathrm{Glu}}\right)$ measured by dual electrode voltage clamp and taken as a measure of electrogenic glutamate transport.

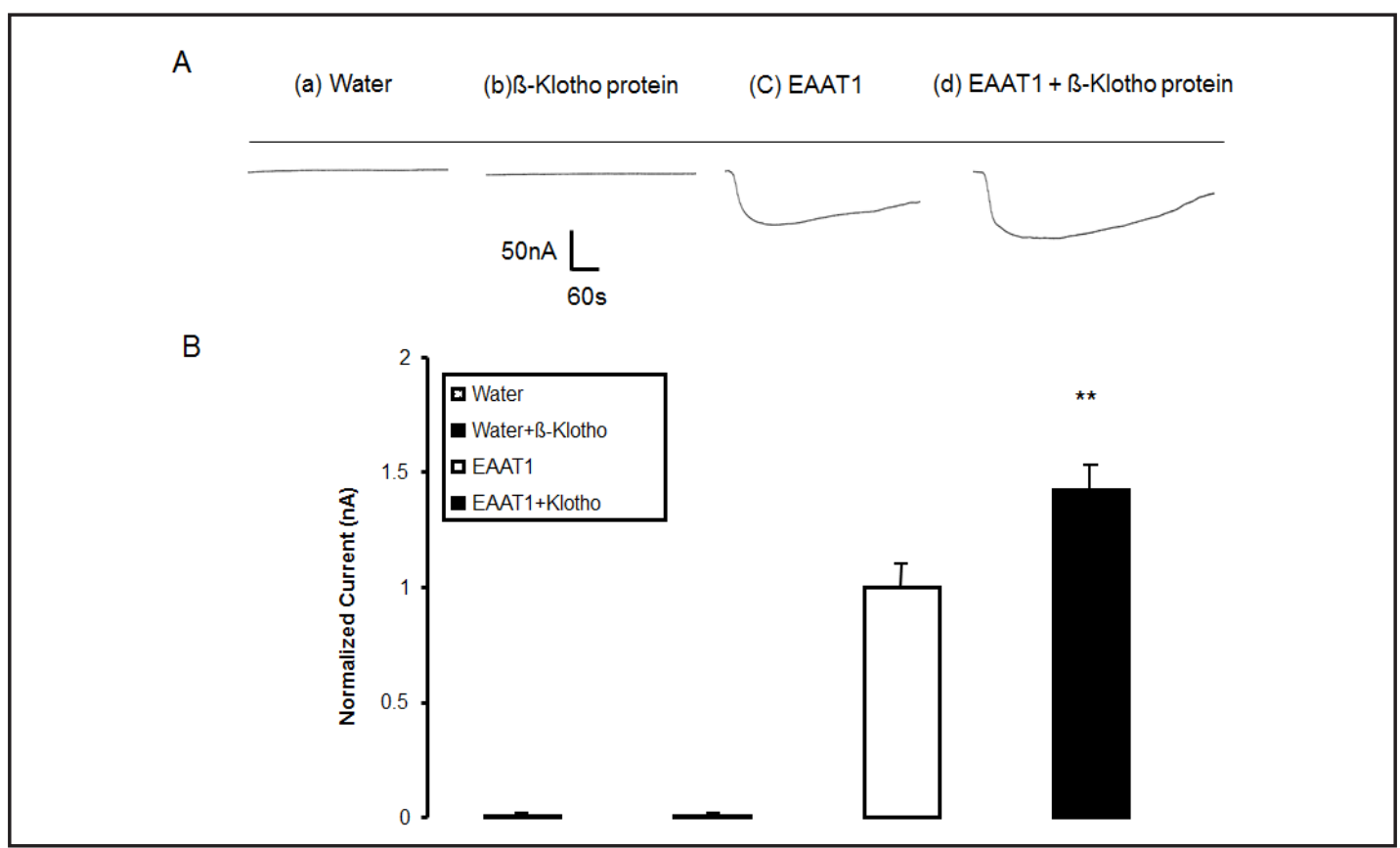

Fig. 1. Effect of recombinant human ß-Klotho protein on electrogenic glutamate transport in EAAT1 expressing Xenopus laevis oocytes. A: Representative original tracings of glutamate $(2 \mathrm{mM})$ induced current in Xenopus oocytes injected with water $(\mathrm{a}, \mathrm{b})$, or with cRNA encoding EAAT1 $(\mathrm{c}, \mathrm{d})$ without $(\mathrm{a}, \mathrm{c})$ and with $(b, d)$ prior $\beta$-Klotho protein $(30 \mathrm{ng} / \mathrm{ml}, 24 \mathrm{~h})$ treatment. B: Arithmetic means \pm SEM $(\mathrm{n}=10-14)$ of the normalized glutamate $(2 \mathrm{mM}$ ) induced current in Xenopus oocytes injected with water (left bars) or expressing EAAT1 (right bars) without (white bars) or with (black bars) prior ß-Klotho protein $(30 \mathrm{ng} / \mathrm{ml}, 24 \mathrm{~h}$ ) treatment. ${ }^{* *}(p<0.01)$ indicates statistically significant difference from EAAT1 expressing oocytes without ß-Klotho protein treatment. 
Fig. 2. Glutamate induced current in EAAT1 expressing Xenopus laevis oocytes as a function of glutamate concentration without and with prior $ß$-Klotho protein treatment. Arithmetic means \pm SEM $(n=3-5)$ of $I_{\text {glu }}$ as a function of glutamate concentration in Xenopus laevis oocytes expressing EAAT1 without (black squares), or with (black circles) prior ß-Klotho protein (30 ng/ml, $24 \mathrm{~h}$ ) treatment. *** $(p<0.001)$ indicates statistically significant difference from untreated EAAT1 expressing oocytes.

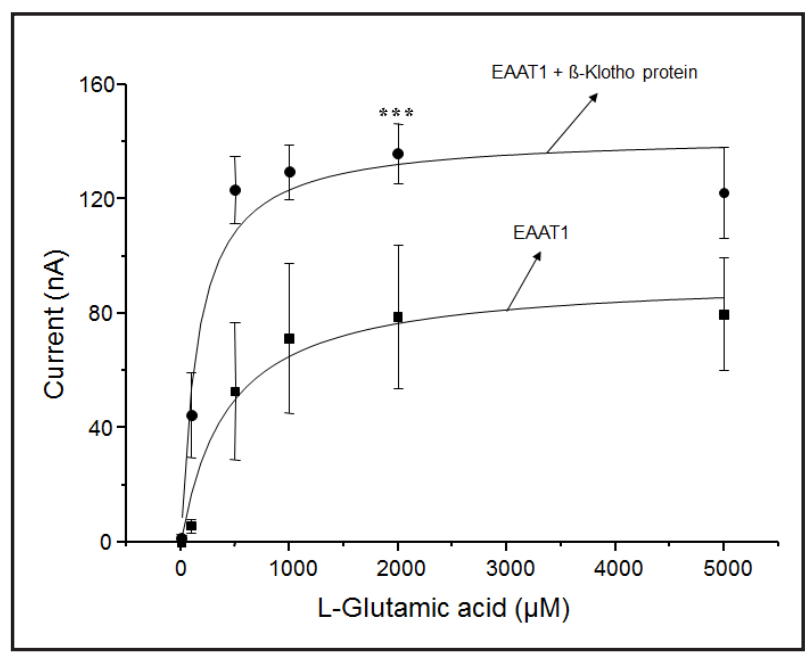

A

(a) Water

(b) EAAT1

(c) EAAT1 + B-Klotho protein

(d) EAAT1 + B-Klotho protein + DSAL
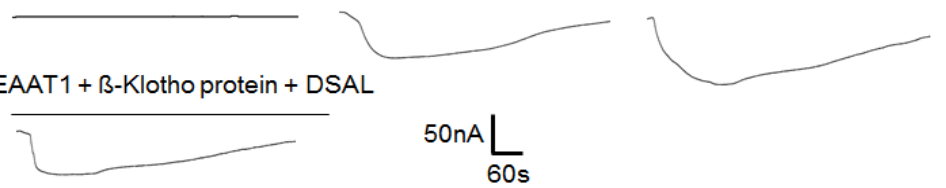

B

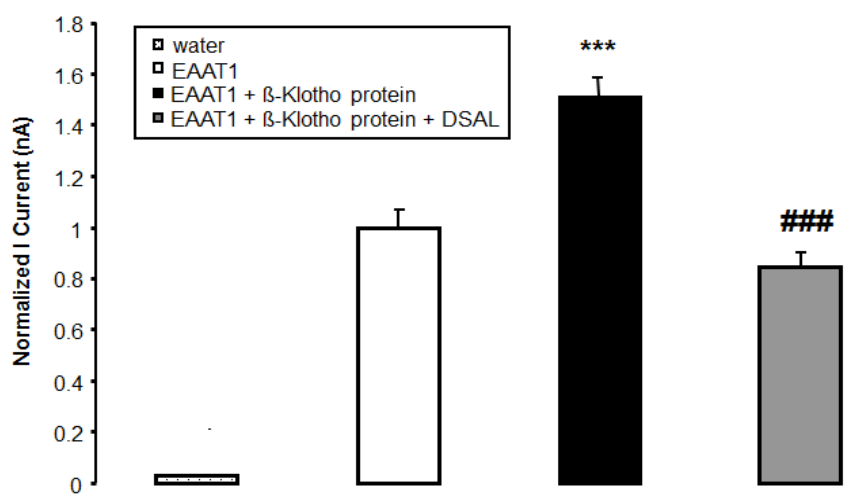

Fig. 3. Effect of recombinant human $ß$-Klotho protein in the absence and presence of $\beta$-glucuronidase inhibitor DSAL on electrogenic glutamate transport in EAAT1 expressing Xenopus laevis oocytes. A: Representative original tracings of glutamate $(2 \mathrm{mM}$ ) induced current in Xenopus oocytes injected with water (a), or with cRNA encoding EAAT1 (b,c,d) without treatment (b) and with treatment with ß-Klotho protein (30 ng/ $\mathrm{ml}, 24 \mathrm{~h}$ ) alone (c) or together with $\beta$-glucuronidase inhibitor D-saccharic acid 1,4-lactone monohydrate $(D S A L, 10 \mu M)(d)$. B: Arithmetic means \pm SEM $(n=11-12)$ of the normalized glutamate $(2 \mathrm{mM})$ induced current in Xenopus oocytes injected with water (dotted bar) or expressing EAAT1 without (white bars) or with prior ß-Klotho protein $(30 \mathrm{ng} / \mathrm{ml}, 24 \mathrm{~h}$ ) treatment alone (black bar) or together with $\beta$-glucuronidase inhibitor D-saccharic acid 1,4-lactone monohydrate (DSAL,10 $\mu \mathrm{M}$ ) (grey bar). ${ }^{* * *}(p<0.001)$ indicates statistically significant difference from respective oocytes without $ß$-Klotho protein treatment, \#\#\# $(p<0.001)$ indicates statistically significant difference from respective oocytes without presence of DSAL.

As illustrated in Fig. 1, $\mathrm{I}_{\text {Glu }}$ was negligible in water-injected oocytes indicating that the oocytes did not express appreciable endogenous electrogenic glutamate transport. In contrast, glutamate ( $2 \mathrm{mM}$ ) triggered a sizable $\mathrm{I}_{\text {Glu }}$ in EAAT1 expressing Xenopus laevis oocytes. The treatment of EAAT1 expressing oocytes with ß-Klotho protein (30 ng/ml) was 
A

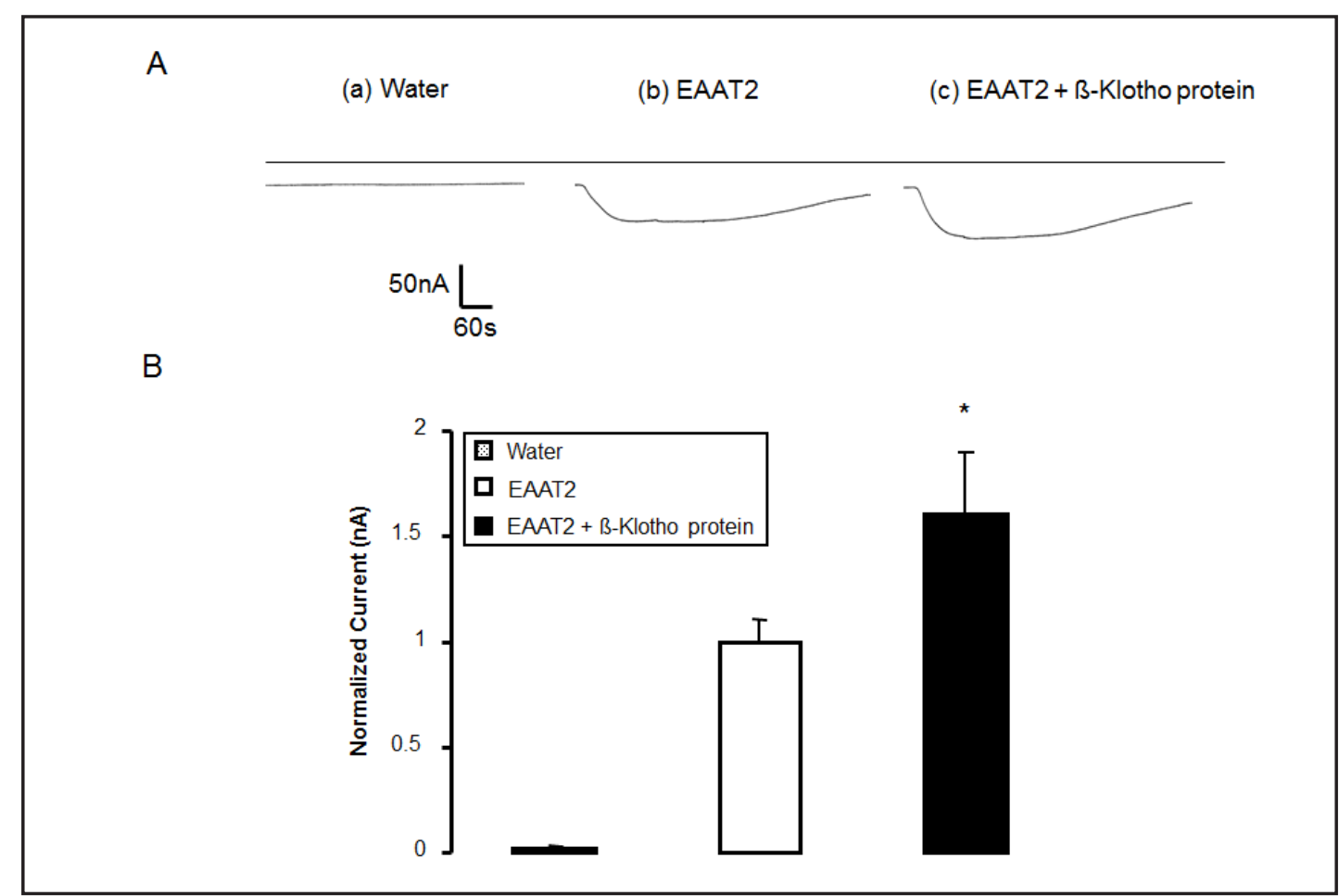

Fig. 4. Effect of recombinant human $ß$-Klotho protein on electrogenic glutamate transport in EAAT2 expressing Xenopus laevis oocytes. A: Representative original tracings of glutamate $(2 \mathrm{mM})$ induced current in Xenopus oocytes injected with water (a), or with cRNA encoding EAAT2 without (b) or with (c) prior ß-Klotho protein $(30 \mathrm{ng} / \mathrm{ml}, 24 \mathrm{~h})$ treatment. B: Arithmetic means \pm SEM $(\mathrm{n}=7-10)$ of the normalized glutamate (2 mM) induced current in Xenopus oocytes injected water (dotted bar) or expressing EAAT2 without (white bar) or with (black bars) prior $ß$-Klotho protein $(30 \mathrm{ng} / \mathrm{ml}, 24 \mathrm{~h})$ treatment. $*(p<0.05)$ indicates statistically significant difference from EAAT2 expressing oocytes without $ß$-Klotho protein treatment.

followed by a significant increase of $\mathrm{I}_{\text {Glu" }}$ Treatment of water injected oocytes with ß-klotho protein $(30 \mathrm{ng} / \mathrm{ml})$ failed to increase $\mathrm{I}_{\text {Glu" }}$.

In order to test whether $ß$-Klotho protein modifies the maximal $\mathrm{I}_{\mathrm{Glu}}$ and/or the affinity of EAAT1, untreated or ß-Klotho protein $(30 \mathrm{ng} / \mathrm{ml}$ ) treated EAAT1 expressing Xenopus laevis oocytes were exposed to L-glutamate concentrations ranging from $10 \mu \mathrm{M}$ to $5000 \mu \mathrm{M}$. As illustrated in Fig. 2, $\mathrm{I}_{\text {Glu }}$ was a function of the extracellular glutamate concentration. Maximal $\mathrm{I}_{\text {Glu }}$ was significantly $(p<0.05)$ higher in $ß$-Klotho protein treated $(146.3 \pm 12.4 \mathrm{nA}, \mathrm{n}=5)$ than in untreated $(102.9 \pm 11.3 \mathrm{nA}, \mathrm{n}=3)$ EAAT1 expressing Xenopus laevis oocytes. The concentration required for half maximal $\mathrm{I}_{\text {Glu }}$ (apparent $\mathrm{K}_{\mathrm{m}}$ ) tended to be lower in ß-Klotho protein treated $(208 \pm 85 \mu \mathrm{M}, \mathrm{n}=5)$ than in untreated $(553 \pm 227 \mu \mathrm{M}, \mathrm{n}=3)$ EAAT1 expressing Xenopus laevis oocytes, a difference, however, not reaching statistical significance.

A further series of experiments explored whether the effect of $B$-Klotho protein is related to its $\beta$-glucuronidase activity. To this end EAAT1 expressing Xenopus laevis oocytes were treated with $\beta$-Klotho protein in the absence and presence of $\beta$-glucuronidase inhibitor D-saccharic acid 1,4-lactone monohydrate (DSAL). As illustrated in Fig. 3, the effect of ß-Klotho protein on electrogenic glutamate transport in EAAT1 expressing Xenopus laevis oocytes was virtually abolished by DSAL $(10 \mu \mathrm{M})$. This observation is highly suggestive that klotho is effective as enzyme.

Similar observations were made in EAAT2 expressing Xenopus laevis oocytes. As illustrated in Fig. 4, glutamate (2 mM) triggered a sizable $\mathrm{I}_{\text {Glu }}$ in EAAT2 expressing Xenopus laevis oocytes. The treatment of EAAT2 expressing oocytes with ß-klotho protein $(30 \mathrm{ng} / \mathrm{ml})$ was followed by a significant increase of $\mathrm{I}_{\text {Glu" }}$. 
Fig. 5. Glutamate induced current in EAAT2 expressing Xenopus laevis oocytes as a function of glutamate concentration without and with prior ß-Klotho protein treatment. Arithmetic means \pm SEM $(n=6-7)$ of $I_{\text {glu }}$ as a function of glutamate concentration in Xenopus laevis oocytes expressing EAAT2 without (black squares), or with (black circles) prior ß-Klotho protein $(30 \mathrm{ng} / \mathrm{ml}, 24 \mathrm{~h})$ treatment. ${ }^{* * *}(p<0.001)$ indicates statistically significant difference from untreated EAAT2 expressing oocytes.

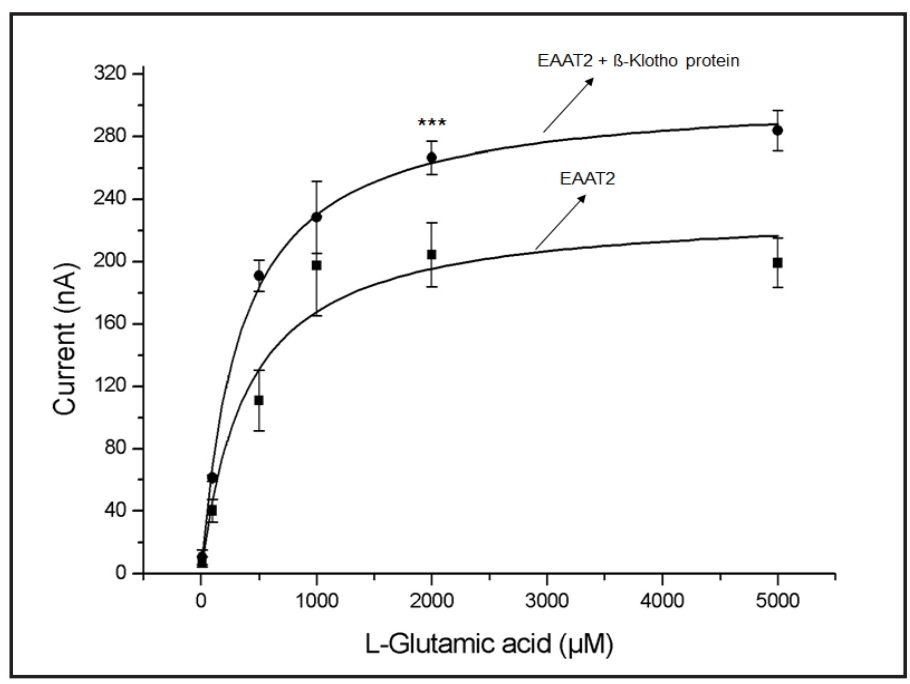

Exposure of EAAT2 expressing oocytes to glutamate concentrations ranging from $10 \mu \mathrm{M}$ to $5000 \mu \mathrm{M}$ revealed the dependence of $\mathrm{I}_{\text {Glu }}$ on extracellular L-glutamate concentration (Fig. 5). Maximal $\mathrm{I}_{\text {Glu }}$ was again significantly $(p<0.05)$ higher in $ß$-Klotho protein treated $(310.0 \pm$ $14.6 \mathrm{nA}, \mathrm{n}=7)$ than in untreated $(242.6 \pm 21.6 \mathrm{nA}, \mathrm{n}=6)$ EAAT2 expressing Xenopus laevis oocytes. The concentration required for half maximal $\mathrm{I}_{\text {Glu }}$ (apparent $\mathrm{K}_{\mathrm{m}}$ ) tended again to be lower in $ß$-Klotho protein treated $(354 \pm 38 \mu \mathrm{M}, \mathrm{n}=7)$ than in untreated $(550 \pm 71 \mu \mathrm{M}$, $\mathrm{n}=6$ ) EAAT2 expressing Xenopus laevis oocytes, a difference again not reaching statistical significance.

A further series of experiments again revealed that the effect of $ß$-Klotho protein was related to its $\beta$-glucuronidase activity. As illustrated in Fig. 6, the effect of $ß$-Klotho protein on electrogenic glutamate transport in EAAT2 expressing Xenopus laevis oocytes was virtually abolished by DSAL $(10 \mu \mathrm{M})$.

\section{Discussion}

The present study reveals a novel function of $ß$-Klotho protein, i.e. the up-regulation of the excitatory amino acid transporters EAAT1 and EAAT2. Treatment of either, EAAT1 and EAAT2 expressing oocytes with human recombinant ß-Klotho significantly increased the glutamate-induced inward current $\left(\mathrm{I}_{\mathrm{Glu}}\right)$. Kinetic analysis reveals that $ß$-Klotho is in large part effective by increasing maximal transport rate of the carriers. The large scatter of the calculated concentrations required for half maximal current precludes safe conclusions about the effect of klotho on carrier affinity. The effect of $ß$-Klotho on $\mathrm{I}_{\text {Glu }}$ is virtually abolished by $\beta$-glucuronidase inhibitor D-saccharic acid 1,4-lactone monohydrate DSAL, an observation suggesting that $ß$-klotho is effective as enzyme. The beta-glucuronidase Klotho belongs to the $\beta$-glycosidase family [84]. As first shown for the $\mathrm{Ca}^{2+}$ channel TRPV5, the enzyme hydrolyzes extracellular sugar residues of target membrane proteins and by this means stabilizes the proteins in the cell membrane [84]. Thus, klotho may increase EAAT activity by stabilizing the carrier protein in the cell membrane. However, the current was significantly lower in klotho and DSAL treated oocytes than in untreated ooytes. We thus cannot exclude that DSAL modifies EAAT1 and EAAT2 by mechanisms other than inhibition of klotho enzyme activity. Along those lines, we cannot rule out that klotho is effective by mechanisms other than betaglucuronidase activity.

Up-regulation of EAAT1 and EAAT2 by ß-Klotho were expected to stimulate the clearance of glutamate from the synaptic cleft and thus to accelerate termination of excitation. Upregulation of excitatory glutamate transporters would thus decrease neuroexcitablity. 
A
(a) Water

(b) EAAT2

(c) EAAT2 + ß-Klotho protein

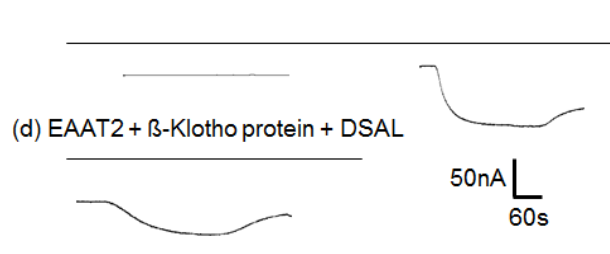

B

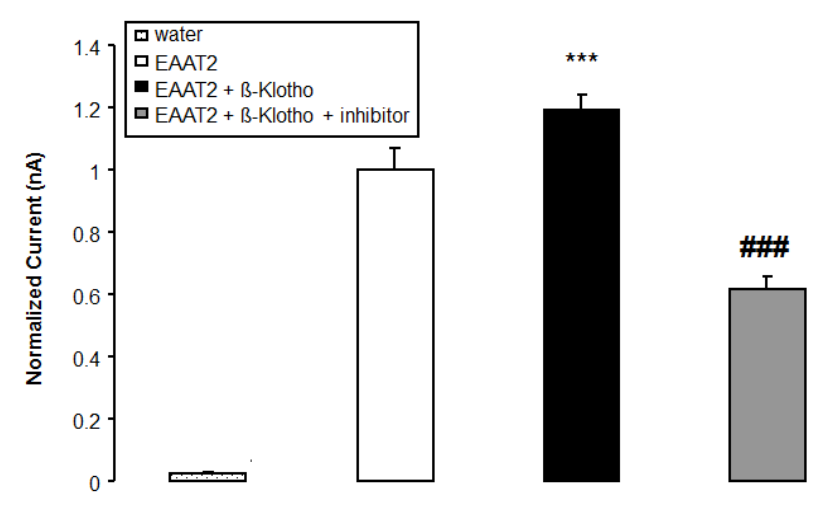

Fig. 6. Effect of recombinant human $ß$-Klotho protein in the absence and presence of $\beta$-glucuronidase inhibitor DSAL on electrogenic glutamate transport in EAAT2 expressing Xenopus laevis oocytes. A: Representative original tracings of glutamate $(2 \mathrm{mM})$ induced current in Xenopus oocytes injected with water (a), or with cRNA encoding EAAT2 (b,c,d) without treatment (b) and with treatment with ß-Klotho protein (30 ng/ $\mathrm{ml}, 24 \mathrm{~h}$ ) alone (c) or together with $\beta$-glucuronidase inhibitor D-saccharic acid 1,4-lactone monohydrate $(\mathrm{DSAL}, 10 \mu \mathrm{M})(\mathrm{d})$. B: Arithmetic means \pm SEM $(\mathrm{n}=14-16)$ of the normalized glutamate $(2 \mathrm{mM})$ induced current in Xenopus oocytes injected water (dotted bar) or expressing EAAT2 without (white bars) or with prior ß-Klotho protein ( $30 \mathrm{ng} / \mathrm{ml}, 24 \mathrm{~h}$ ) treatment alone (black bar) or together with $\beta$-glucuronidase inhibitor D-saccharic acid 1,4-lactone monohydrate (DSAL,10 $\mu \mathrm{M})$ (grey bar). ${ }^{* * *}(p<0.001)$ indicates statistically significant difference from respective oocytes without $ß$-Klotho protein treatment, \#\#\# $(p<0.001)$ indicates statistically significant difference from respective oocytes without presence of DSAL.

Ample evidence points to a role of EAAT1 and EAAT2 in the regulation of neuroexcitation. EAAT1 deficiency in mice results in locomotor hyperactivity, abnormal behavior with reduced preference for a novel social stimulus, reduced acoustic startle response, and impaired memory consolidation in mice $[85,86]$. EAAT2 deficiency in humans may be involved in the pathophysiology of several neurological disorders including Alzheimer disease [87, 88], schizophrenia [89], HIV associated dementia [90], multiple sclerosis [91, 92], leukomalacia [93], epilepsy [94, 95], brain trauma [96], hypoxia and stroke [30, 97-99], reward dependence [100], as well as amyotrophic lateral sclerosis (ALS) [61, 101, 102]. Additional experimental evidence is needed to test whether altered expression and/or function of ß-Klotho contributes to the clinical course of those diseases.

Beyond its influence on EAAT1 and EAAT2, Klotho modifies a variety of channels, carriers, and the $\mathrm{Na}^{+} / \mathrm{K}^{+}$ATPase, which are partially expected to impact on neuronal function. Moreover, the beta-glucuronidase activity could modify and stabilize further cell membrane proteins, such as receptors. Clearly, additional experimentation is required to dissect the various actions of Klotho on neuronal function.

In conclusion, $ß$-Klotho up-regulates the activity of the glutamate transporters EAAT1 and EAAT2. The effect could contribute to the complex regulation of neuronal excitability. 


\section{SíiNAIS}

\begin{tabular}{l}
\hline Neurosignals 2015;23:59-70 \\
\begin{tabular}{l|l}
\hline DOI: 10.1159/000442604 & C 2015 The Author(s). Published by S. Karger AG, Basel \\
Published onlIne: December 19, 2015 & www.karger.com/nsg
\end{tabular} \\
\hline
\end{tabular}

Warsi/Abousaab/Lang: Klotho Sensitivity of EAAT1 and EAAT2

\section{Acknowledgements}

The authors acknowledge the meticulous preparation of the manuscript by Lejla Subasic and technical support by Elfriede Faber. This study was supported by the Deutsche Forschungsgemeinschaft.

\section{Disclosure Statement}

The authors declare that they have nothing to disclose.

\section{References}

1 Takeshita K, Fujimori T, Kurotaki Y, Honjo H, Tsujikawa H, Yasui K, Lee JK, Kamiya K, Kitaichi K, Yamamoto K, Ito M, Kondo T, Iino S, Inden Y, Hirai M, Murohara T, Kodama I, Nabeshima Y: Sinoatrial node dysfunction and early unexpected death of mice with a defect of klotho gene expression. Circulation 2004;109:17761782.

-2 Tsujikawa H, Kurotaki Y, Fujimori T, Fukuda K, Nabeshima Y: Klotho, a gene related to a syndrome resembling human premature aging, functions in a negative regulatory circuit of vitamin D endocrine system. Mol Endocrinol 2003;17:2393-2403.

3 Cha SK, Ortega B, Kurosu H, Rosenblatt KP, Kuro OM, Huang CL: Removal of sialic acid involving Klotho causes cell-surface retention of TRPV5 channel via binding to galectin-1. Proc Natl Acad Sci U S A 2008;105:9805-9810.

-4 Hu MC, Shi M, Zhang J, Pastor J, Nakatani T, Lanske B, Razzaque MS, Rosenblatt KP, Baum MG, Kuro-o M, Moe OW: Klotho: a novel phosphaturic substance acting as an autocrine enzyme in the renal proximal tubule. FASEB J 2010;24:3438-3450.

-5 Imura A, Iwano A, Tohyama O, Tsuji Y, Nozaki K, Hashimoto N, Fujimori T, Nabeshima Y: Secreted Klotho protein in sera and CSF: implication for post-translational cleavage in release of Klotho protein from cell membrane. FEBS Lett 2004;565:143-147.

6 Leunissen EH, Nair AV, Bull C, Lefeber DJ, van Delft FL, Bindels RJ, Hoenderop JG: The epithelial calcium channel TRPV5 is regulated differentially by klotho and sialidase. J Biol Chem 2013;288:29238-29246.

7 Tohyama O, Imura A, Iwano A, Freund JN, Henrissat B, Fujimori T, Nabeshima Y: Klotho is a novel betaglucuronidase capable of hydrolyzing steroid beta-glucuronides. J Biol Chem 2004;279:9777-9784.

8 Kuro-o M: Klotho. Pflugers Arch 2010;459:333-343.

-9 Kuro-o M, Matsumura Y, Aizawa H, Kawaguchi H, Suga T, Utsugi T, Ohyama Y, Kurabayashi M, Kaname T, Kume E, Iwasaki H, Iida A, Shiraki-Iida T, Nishikawa S, Nagai R, Nabeshima YI: Mutation of the mouse klotho gene leads to a syndrome resembling ageing. Nature 1997;390:45-51.

10 Kuro-o M: Klotho. Pflugers Arch. 2010;459:333-343.

11 Abed M, Feger M, Alzoubi K, Pakladok T, Frauenfeld L, Geiger C, Towhid ST, Lang F: Sensitization of erythrocytes to suicidal erythrocyte death following water deprivation. Kidney Blood Press Res 2013;37:567-578.

-12 Feger M, Fajol A, Lebedeva A, Meissner A, Michael D, Voelkl J, Alesutan I, Schleicher E, Reichetzeder C, Hocher B, Qadri SM, Lang F: Effect of carbon monoxide donor CORM-2 on vitamin D3 metabolism. Kidney Blood Press Res 2013;37:496-505.

13 Razzaque MS, Sitara D, Taguchi T, St-Arnaud R, Lanske B: Premature aging-like phenotype in fibroblast growth factor 23 null mice is a vitamin D-mediated process. FASEB J 2006;20:720-722.

14 Yoshida T, Fujimori T, Nabeshima Y: Mediation of unusually high concentrations of 1,25-dihydroxyvitamin D in homozygous klotho mutant mice by increased expression of renal 1alpha-hydroxylase gene. Endocrinology 2002;143:683-689.

15 Alesutan I, Feger M, Pakladok T, Mia S, Ahmed MS, Voelkl J, Lang F: 25-Hydroxyvitamin D3 1-alphahydroxylase-dependent stimulation of renal klotho expression by spironolactone. Kidney Blood Press Res 2013;37:475-487. 
16 Ramasamy I: Recent advances in physiological calcium homeostasis. Clin Chem Lab Med 2006;44:237-273.

17 Segawa H, Yamanaka S, Ohno Y, Onitsuka A, Shiozawa K, Aranami F, Furutani J, Tomoe Y, Ito M, Kuwahata M, Imura A, Nabeshima Y, Miyamoto K: Correlation between hyperphosphatemia and type II Na-Pi cotransporter activity in klotho mice. Am J Physiol Renal Physiol 2007;292:F769-779.

18 Kuro-o M: Klotho as a regulator of fibroblast growth factor signaling and phosphate/calcium metabolism. Curr Opin Nephrol Hypertens 2006;15:437-441.

19 Ohnishi M, Nakatani T, Lanske B, Razzaque MS: Reversal of mineral ion homeostasis and soft-tissue calcification of klotho knockout mice by deletion of vitamin D 1alpha-hydroxylase. Kidney Int 2009;75:1166-1172.

20 Boros S, Bindels RJ, Hoenderop JG: Active Ca(2+) reabsorption in the connecting tubule. Pflugers Arch 2009;458:99-109.

21 Dermaku-Sopjani M, Sopjani M, Saxena A, Shojaiefard M, Bogatikov E, Alesutan I, Eichenmuller M, Lang F: Downregulation of NaPi-IIa and NaPi-IIb Na-coupled phosphate transporters by coexpression of Klotho. Cell Physiol Biochem 2011;28:251-258.

22 Sopjani M, Alesutan I, Dermaku-Sopjani M, Gu S, Zelenak C, Munoz C, Velic A, Foller M, Rosenblatt KP, Kuro-o M, Lang F: Regulation of the Na+/K+ ATPase by Klotho. FEBS Lett 2011;585:1759-1764.

23 Cha SK, Hu MC, Kurosu H, Kuro-o M, Moe O, Huang CL: Regulation of renal outer medullary potassium channel and renal K(+) excretion by Klotho. Mol Pharmacol 2009;76:38-46.

-24 Almilaji A, Pakladok T, Munoz C, Elvira B, Sopjani M, Lang F: Upregulation of KCNQ1/KCNE1 K+ channels by Klotho. Channels (Austin) 2014;8:222-229.

25 Almilaji A, Munoz C, Pakladok T, Alesutan I, Feger M, Foller M, Lang UE, Shumilina E, Lang F: Klotho sensitivity of the neuronal excitatory amino acid transporters EAAT3 and EAAT4. PLoS One 2013;8:e70988.

-26 Beart PM, O'Shea RD: Transporters for L-glutamate: an update on their molecular pharmacology and pathological involvement. Br J Pharmacol 2007;150:5-17.

27 Estrada Sanchez AM, Mejia-Toiber J, Massieu L: Excitotoxic neuronal death and the pathogenesis of Huntington's disease. Arch Med Res 2008;39:265-276.

-28 Foran E, Trotti D: Glutamate transporters and the excitotoxic path to motor neuron degeneration in amyotrophic lateral sclerosis. Antioxid Redox Signal 2009;11:1587-1602.

29 Markowitz AJ, White MG, Kolson DL, Jordan-Sciutto KL: Cellular interplay between neurons and glia: toward a comprehensive mechanism for excitotoxic neuronal loss in neurodegeneration. Cellscience 2007;4:111-146.

-30 Sheldon AL, Robinson MB: The role of glutamate transporters in neurodegenerative diseases and potential opportunities for intervention. Neurochem Int 2007;51:333-355.

31 Amara SG, Fontana AC: Excitatory amino acid transporters: keeping up with glutamate. Neurochem Int 2002;41:313-318.

-32 Lehre KP, Danbolt NC: The number of glutamate transporter subtype molecules at glutamatergic synapses: chemical and stereological quantification in young adult rat brain. J Neurosci 1998;18:8751-8757.

33 Berger UV, Hediger MA: Comparative analysis of glutamate transporter expression in rat brain using differential double in situ hybridization. Anat Embryol (Berl) 1998;198:13-30.

-34 Cholet N, Pellerin L, Magistretti PJ, Hamel E: Similar perisynaptic glial localization for the Na+,K+-ATPase alpha 2 subunit and the glutamate transporters GLAST and GLT-1 in the rat somatosensory cortex. Cereb Cortex 2002;12:515-525.

-35 Fukaya M, Yamada K, Nagashima M, Tanaka K, Watanabe M: Down-regulated expression of glutamate transporter GLAST in Purkinje cell-associated astrocytes of reeler and weaver mutant cerebella. Neurosci Res 1999;34:165-175.

36 Kimmich GA, Roussie J, Manglapus M, Randles J: Characterization of Na+-coupled glutamate/aspartate transport by a rat brain astrocyte line expressing GLAST and EAAC1. J Membr Biol 2001;182:17-30.

-37 Sandhu JK, Sikorska M, Walker PR: Characterization of astrocytes derived from human NTera-2/D1 embryonal carcinoma cells. J Neurosci Res 2002;68:604-614.

-38 Suarez I, Bodega G, Fernandez B: Modulation of glutamate transporters (GLAST, GLT-1 and EAAC1) in the rat cerebellum following portocaval anastomosis. Brain Res 2000;859:293-302. 


\section{SIGiNAis}

Neurosignals 2015;23:59-70

\begin{tabular}{l|l}
\hline DOI: 10.1159/000442604 & (c) 2015 The Author(s). Published by S. Karger AG, Basel \\
Publisned onIIne: December 19, 2015 & www.karger.com/nsg
\end{tabular}

Warsi/Abousaab/Lang: Klotho Sensitivity of EAAT1 and EAAT2

-39 Suzuki K, Ikegaya Y, Matsuura S, Kanai Y, Endou H, Matsuki N: Transient upregulation of the glial glutamate transporter GLAST in response to fibroblast growth factor, insulin-like growth factor and epidermal growth factor in cultured astrocytes. J Cell Sci 2001;114:3717-3725.

40 Ullensvang K, Lehre KP, Storm-Mathisen J, Danbolt NC: Differential developmental expression of the two rat brain glutamate transporter proteins GLAST and GLT. Eur J Neurosci 1997;9:1646-1655.

41 Utsumi M, Ohno K, Onchi H, Sato K, Tohyama M: Differential expression patterns of three glutamate transporters (GLAST, GLT1 and EAAC1) in the rat main olfactory bulb. Brain Res Mol Brain Res 2001;92:111.

42 Milton ID, Banner SJ, Ince PG, Piggott NH, Fray AE, Thatcher N, Horne CH, Shaw PJ: Expression of the glial glutamate transporter EAAT2 in the human CNS: an immunohistochemical study. Brain Res Mol Brain Res 1997;52:17-31.

43 Domercq M, Matute C: Expression of glutamate transporters in the adult bovine corpus callosum. Brain Res Mol Brain Res 1999;67:296-302.

44 Domercq M, Sanchez-Gomez MV, Areso P, Matute C: Expression of glutamate transporters in rat optic nerve oligodendrocytes. Eur J Neurosci 1999;11:2226-2236.

45 Gaillet S, Plachez C, Malaval F, Bezine MF, Recasens M: Transient increase in the high affinity [3H]-Lglutamate uptake activity during in vitro development of hippocampal neurons in culture. Neurochem Int 2001;38:293-301.

46 Plachez C, Danbolt NC, Recasens M: Transient expression of the glial glutamate transporters GLAST and GLT in hippocampal neurons in primary culture. J Neurosci Res 2000;59:587-593.

47 Rothstein JD, Martin L, Levey AI, Dykes-Hoberg M, Jin L, Wu D, Nash N, Kuncl RW: Localization of neuronal and glial glutamate transporters. Neuron 1994;13:713-725.

48 Barnett NL, Pow DV: Antisense knockdown of GLAST, a glial glutamate transporter, compromises retinal function. Invest Ophthalmol Vis Sci 2000;41:585-591.

49 Derouiche A, Rauen T: Coincidence of L-glutamate/L-aspartate transporter (GLAST) and glutamine synthetase (GS) immunoreactions in retinal glia: evidence for coupling of GLAST and GS in transmitter clearance. J Neurosci Res 1995;42:131-143.

50 Lawton DM, Furness DN, Lindemann B, Hackney CM: Localization of the glutamate-aspartate transporter, GLAST, in rat taste buds. Eur J Neurosci 2000;12:3163-3171.

51 Furness DN, Lehre KP: Immunocytochemical localization of a high-affinity glutamate-aspartate transporter, GLAST, in the rat and guinea-pig cochlea. Eur J Neurosci 1997;9:1961-1969.

52 Li HS, Niedzielski AS, Beisel KW, Hiel H, Wenthold RJ, Morley BJ: Identification of a glutamate/aspartate transporter in the rat cochlea. Hear Res 1994;78:235-242.

53 Takumi Y, Matsubara A, Danbolt NC, Laake JH, Storm-Mathisen J, Usami S, Shinkawa H, Ottersen OP: Discrete cellular and subcellular localization of glutamine synthetase and the glutamate transporter GLAST in the rat vestibular end organ. Neuroscience 1997;79:1137-1144.

54 Lee JA, Long Z, Nimura N, Iwatsubo T, Imai K, Homma H: Localization, transport, and uptake of D-aspartate in the rat adrenal and pituitary glands. Arch Biochem Biophys 2001;385:242-249.

-55 Redecker P, Pabst H: Immunohistochemical study of the glutamate transporter proteins GLT-1 and GLAST in rat and gerbil pineal gland. J Pineal Res 2000;28:179-184.

56 Gray C, Marie H, Arora M, Tanaka K, Boyde A, Jones S, Attwell D: Glutamate does not play a major role in controlling bone growth. J Bone Miner Res 2001;16:742-749.

57 Huggett J, Vaughan-Thomas A, Mason D: The open reading frame of the $\mathrm{Na}(+)$-dependent glutamate transporter GLAST-1 is expressed in bone and a splice variant of this molecule is expressed in bone and brain. FEBS Lett 2000;485:13-18.

58 Mason DJ, Suva LJ, Genever PG, Patton AJ, Steuckle S, Hillam RA, Skerry TM: Mechanically regulated expression of a neural glutamate transporter in bone: a role for excitatory amino acids as osteotropic agents? Bone 1997;20:199-205.

59 Nomura S, Takano-Yamamoto T: Molecular events caused by mechanical stress in bone. Matrix Biol 2000;19:91-96.

60 Rothstein JD, Patel S, Regan MR, Haenggeli C, Huang YH, Bergles DE, Jin L, Dykes Hoberg M, Vidensky S, Chung DS, Toan SV, Bruijn LI, Su ZZ, Gupta P, Fisher PB: Beta-lactam antibiotics offer neuroprotection by increasing glutamate transporter expression. Nature 2005;433:73-77. 
61 Gibb SL, Boston-Howes W, Lavina ZS, Gustincich S, Brown RH, Jr., Pasinelli P, Trotti D: A caspase-3-cleaved fragment of the glial glutamate transporter EAAT2 is sumoylated and targeted to promyelocytic leukemia nuclear bodies in mutant SOD1-linked amyotrophic lateral sclerosis. J Biol Chem 2007;282:32480-32490.

62 Rothstein JD, Dykes-Hoberg M, Pardo CA, Bristol LA, Jin L, Kuncl RW, Kanai Y, Hediger MA, Wang Y, Schielke JP, Welty DF: Knockout of glutamate transporters reveals a major role for astroglial transport in excitotoxicity and clearance of glutamate. Neuron 1996;16:675-686.

63 Tanaka K, Watase K, Manabe T, Yamada K, Watanabe M, Takahashi K, Iwama H, Nishikawa T, Ichihara N, Kikuchi T, Okuyama S, Kawashima N, Hori S, Takimoto M, Wada K: Epilepsy and exacerbation of brain injury in mice lacking the glutamate transporter GLT-1. Science 1997;276:1699-1702.

64 Vorwerk CK, Naskar R, Schuettauf F, Quinto K, Zurakowski D, Gochenauer G, Robinson MB, Mackler SA, Dreyer EB: Depression of retinal glutamate transporter function leads to elevated intravitreal glutamate levels and ganglion cell death. Invest Ophthalmol Vis Sci 2000;41:3615-3621.

65 Boehmer C, Henke G, Schniepp R, Palmada M, Rothstein JD, Broer S, Lang F: Regulation of the glutamate transporter EAAT1 by the ubiquitin ligase Nedd4-2 and the serum and glucocorticoid-inducible kinase isoforms SGK1/3 and protein kinase B. J Neurochem 2003;86:1181-1188.

66 Boehmer C, Palmada M, Rajamanickam J, Schniepp R, Amara S, Lang F: Post-translational regulation of EAAT2 function by co-expressed ubiquitin ligase Nedd4-2 is impacted by SGK kinases. J Neurochem 2006;97:911-921.

67 Gehring EM, Zurn A, Klaus F, Laufer J, Sopjani M, Lindner R, Strutz-Seebohm N, Tavare JM, Boehmer C, Palmada M, Lang UE, Seebohm G, Lang F: Regulation of the glutamate transporter EAAT2 by PIKfyve. Cell Physiol Biochem 2009;24:361-368.

68 Shigeri Y, Shimamoto K, Yasuda-Kamatani Y, Seal RP, Yumoto N, Nakajima T, Amara SG: Effects of threo-beta-hydroxyaspartate derivatives on excitatory amino acid transporters (EAAT4 and EAAT5). J Neurochem 2001;79:297-302.

69 Almilaji A, Munoz C, Hosseinzadeh Z, Lang F: Upregulation of Na+,Cl(-)-coupled betaine/gamma-aminobutyric acid transporter BGT1 by Tau tubulin kinase 2. Cell Physiol Biochem 2013;32:334-343.

70 Almilaji A, Sopjani M, Elvira B, Borras J, Dermaku-Sopjani M, Munoz C, Warsi J, Lang UE, Lang F: Upregulation of the creatine transporter Slc6A8 by Klotho. Kidney Blood Press Res 2014;39:516-525.

71 Hosseinzadeh Z, Dong L, Bhavsar SK, Warsi J, Almilaji A, Lang F: Upregulation of peptide transporters PEPT1 and PEPT2 by Janus kinase JAK2. Cell Physiol Biochem 2013;31:673-682.

72 Pakladok T, Almilaji A, Munoz C, Alesutan I, Lang F: PIKfyve sensitivity of hERG channels. Cell Physiol Biochem 2013;31:785-794.

73 Almilaji A, Honisch S, Liu G, Elvira B, Ajay SS, Hosseinzadeh Z, Ahmed M, Munoz C, Sopjani M, Lang F: Regulation of the voltage gated K channel Kv1.3 by recombinant human klotho protein. Kidney Blood Press Res 2014;39:609-622.

74 Almilaji A, Szteyn K, Fein E, Pakladok T, Munoz C, Elvira B, Towhid ST, Alesutan I, Shumilina E, Bock CT, Kandolf R, Lang F: Down-regulation of Na/K+ atpase activity by human parvovirus B19 capsid protein VP1. Cell Physiol Biochem 2013;31:638-648.

75 Fezai M, Elvira B, Borras J, Ben-Attia M, Hoseinzadeh Z, Lang F: Negative regulation of the creatine transporter SLC6A8 by SPAK and OSR1. Kidney Blood Press Res 2014;39:546-554.

76 Dermaku-Sopjani M, Almilaji A, Pakladok T, Munoz C, Hosseinzadeh Z, Blecua M, Sopjani M, Lang F: Downregulation of the Na+-coupled phosphate transporter NaPi-IIa by AMP-activated protein kinase. Kidney Blood Press Res 2013;37:547-556.

77 Elvira B, Munoz C, Borras J, Chen H, Warsi J, Ajay SS, Shumilina E, Lang F: SPAK and OSR1 dependent downregulation of murine renal outer medullary K channel ROMK1. Kidney Blood Press Res 2014;39:353-360.

78 Hosseinzadeh Z, Luo D, Sopjani M, Bhavsar SK, Lang F: Down-regulation of the epithelial Na(+) channel ENaC by Janus kinase 2. J Membr Biol 2014;247:331-338.

79 Hosseinzadeh Z, Sopjani M, Pakladok T, Bhavsar SK, Lang F: Downregulation of KCNQ4 by Janus kinase 2. J Membr Biol 2013;246:335-341.

80 Munoz C, Almilaji A, Setiawan I, Foller M, Lang F: Up-regulation of the inwardly rectifying K(+) channel Kir2.1 (KCNJ2) by protein kinase B (PKB/Akt) and PIKfyve. J Membr Biol 2013;246:189-197.

81 Warsi J, Dong L, Elvira B, Salker MS, Shumilina E, Hosseinzadeh Z, Lang F: SPAK dependent regulation of peptide transporters PEPT1 and PEPT2. Kidney Blood Press Res 2014;39:388-398. 


\section{SiquNAis}

\begin{tabular}{l}
\hline Neurosignals 2015;23:59-70 \\
\begin{tabular}{l|l}
\hline DOI: 10.1159/000442604 & (c) 2015 The Author(s). Published by S. Karger AG, Basel \\
Published onlIne: December 19, 2015 & www.karger.com/nsg
\end{tabular} \\
\hline
\end{tabular}

Warsi/Abousaab/Lang: Klotho Sensitivity of EAAT1 and EAAT2

-82 Warsi J, Elvira B, Bissinger R, Shumilina E, Hosseinzadeh Z, Lang F: Downregulation of peptide transporters PEPT1 and PEPT2 by oxidative stress responsive kinase OSR1. Kidney Blood Press Res 2014;39:591-599.

-83 Warsi J, Hosseinzadeh Z, Elvira B, Bissinger R, Shumilina E, Lang F: Regulation of ClC-2 activity by SPAK and OSR1. Kidney Blood Press Res 2014;39:378-387.

84 Chang Q, Hoefs S, van der Kemp AW, Topala CN, Bindels RJ, Hoenderop JG: The beta-glucuronidase klotho hydrolyzes and activates the TRPV5 channel. Science 2005;310:490-493.

-85 Karlsson RM, Tanaka K, Heilig M, Holmes A: Loss of glial glutamate and aspartate transporter (excitatory amino acid transporter 1 ) causes locomotor hyperactivity and exaggerated responses to psychotomimetics: rescue by haloperidol and metabotropic glutamate 2/3 agonist. Biol Psychiatry 2008;64:810-814.

-86 Karlsson RM, Tanaka K, Saksida LM, Bussey TJ, Heilig M, Holmes A: Assessment of glutamate transporter GLAST (EAAT1)-deficient mice for phenotypes relevant to the negative and executive/cognitive symptoms of schizophrenia. Neuropsychopharmacology 2009;34:1578-1589.

87 Li S, Mallory M, Alford M, Tanaka S, Masliah E: Glutamate transporter alterations in Alzheimer disease are possibly associated with abnormal APP expression. J Neuropathol Exp Neurol 1997;56:901-911.

88 Tian G, Lai L, Guo H, Lin Y, Butchbach ME, Chang Y, Lin CL: Translational control of glial glutamate transporter EAAT2 expression. J Biol Chem 2007;282:1727-1737.

89 Lang UE, Puls I, Muller DJ, Strutz-Seebohm N, Gallinat J: Molecular mechanisms of schizophrenia. Cell Physiol Biochem 2007;20:687-702.

$\$ 90$ Rumbaugh JA, Li G, Rothstein J, Nath A: Ceftriaxone protects against the neurotoxicity of human immunodeficiency virus proteins. J Neurovirol 2007;13:168-172.

91 Pampliega 0, Domercq M, Villoslada P, Sepulcre J, Rodriguez-Antiguedad A, Matute C: Association of an EAAT2 polymorphism with higher glutamate concentration in relapsing multiple sclerosis. J Neuroimmunol 2008;195:194-198.

-92 Vercellino M, Merola A, Piacentino C, Votta B, Capello E, Mancardi GL, Mutani R, Giordana MT, Cavalla P: Altered glutamate reuptake in relapsing-remitting and secondary progressive multiple sclerosis cortex: correlation with microglia infiltration, demyelination, and neuronal and synaptic damage. J Neuropathol Exp Neurol 2007;66:732-739.

-93 Desilva TM, Billiards SS, Borenstein NS, Trachtenberg FL, Volpe JJ, Kinney HC, Rosenberg PA: Glutamate transporter EAAT2 expression is up-regulated in reactive astrocytes in human periventricular leukomalacia. J Comp Neurol 2008;508:238-248.

94 Rakhade SN, Loeb JA: Focal reduction of neuronal glutamate transporters in human neocortical epilepsy. Epilepsia 2008;49:226-236.

95 Rakhade SN, Shah AK, Agarwal R, Yao B, Asano E, Loeb JA: Activity-dependent gene expression correlates with interictal spiking in human neocortical epilepsy. Epilepsia 2007;48 Suppl 5:86-95.

-96 van Landeghem FK, Weiss T, Oehmichen M, von Deimling A: Decreased expression of glutamate transporters in astrocytes after human traumatic brain injury. J Neurotrauma 2006;23:1518-1528.

97 Boycott HE, Dallas M, Boyle JP, Pearson HA, Peers C: Hypoxia suppresses astrocyte glutamate transport independently of amyloid formation. Biochem Biophys Res Commun 2007;364:100-104.

$\$ 98$ Hurtado O, Pradillo JM, Fernandez-Lopez D, Morales JR, Sobrino T, Castillo J, Alborch E, Moro MA, Lizasoain I: Delayed post-ischemic administration of CDP-choline increases EAAT2 association to lipid rafts and affords neuroprotection in experimental stroke. Neurobiol Dis 2008;29:123-131.

99 Munch C, Zhu BG, Mink A, Seefried U, Riepe MW, Ludolph AC, Meyer T: Chemical hypoxia facilitates alternative splicing of EAAT2 in presymptomatic APP23 transgenic mice. Neurochem Res 2008;33:10051010.

100 Matsumoto Y, Suzuki A, Ishii G, Oshino S, Otani K, Goto K: The -181 A/C polymorphism in the excitatory amino acid transporter-2 gene promoter affects the personality trait of reward dependence in healthy subjects. Neurosci Lett 2007;427:99-102.

101 Rothstein JD, Martin LJ, Kuncl RW: Decreased glutamate transport by the brain and spinal cord in amyotrophic lateral sclerosis. N Engl J Med 1992;326:1464-1468.

102 Rothstein JD, Van Kammen M, Levey AI, Martin LJ, Kuncl RW: Selective loss of glial glutamate transporter GLT-1 in amyotrophic lateral sclerosis. Ann Neurol 1995;38:73-84. 